\title{
COMBINATION OF THE PROFILE MATCHING AND TOPSIS METHOD IN DECISION SUPPORT SYSTEM OF LECTURER PERFORMANCE ASSESSMENT
}

\author{
I Putu Dody Suarnatha ${ }^{1 *}$, I Gede Aris Gunadi² \\ Ilmu Komputer \\ Universitas Pendidikan Ganesha \\ www.undiksha.ac.id \\ dody.suarnatha@undiksha.ac.id 1*), igedearisgunadi@undiksha.ac.id 2 \\ (*) Corresponding Author
}

\begin{abstract}
Abstrak
Untuk menghasilkan dosen yang berkompeten serta profesional tentunya memerlukan berbagai upaya agar tujuan tersebut tercapai, salah satu upaya yang dapat dilakukan yaitu melalui penilaian kinerja dosen. Di Universitas Tabanan penilaian kinerja dosen dilaksanakan setiap akhir semester, namun dalam penyelenggaraanya ditemui kendala, yaitu: hasil penilaian yang masih belum sesuai karena hanya melakukan penilaian terhadap kriteria pendidikan dan pembelajaran saja dan tidak mencakup kriteria penentu lainnya, selain itu di Universitas Tabanan belum memiliki tolak ukur penentuan kinerja dosen. Hal ini memiliki dampak pada proses pengambilan keputusan dalam mengevaluasi dan merangking kinerja dosen. Maka dari itu, untuk mengatasi kendala tersebut diperlukanlah suatu sistem pendukung keputusan (SPK). SPK yang dibangun menggunakan gabungan antara metode Profile Matching dan TOPSIS. Metode Profile Matching digunakan pada proses pembobotan dan perhitungan tingkat kecocokan dari masingmasing alternatif sedangkan metode TOPSIS untuk perhitungan perangkingan. Sistem pendukung keputusan yang dibangun menggunakan empat kriteria yang diambil dari sasaran kinerja pegawai (SKP). Kriteria tersebut yaitu : Pendidikan dan Pengajaran, Penelitian, Pengabdian Kepada Masyarakat dan Prilaku Kerja.
\end{abstract}

Kata kunci: Penilaian Kinerja, Profile Matching, TOPSIS, Sistem Pendukung Keputusan

\begin{abstract}
To generate competent and professional lecturers, it absolutely requires various efforts to achieve the goal. an effort that can be conducted is through lecturer performance assessments. At Tabanan University, lecturer performance assessments are conducted at the end of each semester. However, in the implementation there are obstacles, as follow: the results of the assessment are still not appropriate because they only make an assessment of the education and learning criteria and they do not include other determining criteria. Besides, at Tabanan University, there is no rejection measure the determination of lecturer performance. This has an impact on the decision-making process in evaluating and ranking lecturers' performance. Therefore, to overcome these obstacles, a decision support system (DSS) is needed. The DSS was built using a combination of Profile Matching and TOPSIS methods. The Profile Matching method was used in the process of weighting and calculating the suitability of each alternative, while the TOPSIS method was used for ranking calculations. The decision support system that was built used four criteria taken from the employee performance targets (SKP). The criteria were: Education and Teaching, Research, Community Service and Work Behavior.
\end{abstract}

Keywords: Performance assessment, Profile Matching, TOPSIS, Decision Support System

\section{INTRODUCTION}

Lecturers are scientists and professional educators who play highly important roles, have responsibilities and tasks in realizing the goals of national education, namely educating the nation's life and improving the quality of Indonesian human resources (Latief, 2018). To produce professional and competent lecturers, it absolutely requires a measurable and continuous effort. An effort that can be conducted is through performance appraisal. Assessment of lecturer performance in higher education is an activity to evaluate and assess the performance of each existing lecturer. This assessment is highly important in improving the internal quality of higher education in a sustainable manner. 
Tabanan University or well-known as UNTAB conducts performance assessments of lecturers at the end of each semester (odd/even). The assessment is carried out by distributing questionnaires to students while carrying out the final semester exams. Furthermore, The results of the questionnaire assessment are collected for the purposes of Study Programs and Faculties during the Accreditation process (Agustini, 2017). In the implementation, it found obstacles such as the results of the lecturer's performance assessment being incomplete because it only assessed the education and learning criteria and did not include other determining criteria. Besides, UNTAB has not had a benchmark in assessing the performance of lecturers. This has an impact on the performance evaluation process (Kusumastuti et al., 2019). Therefore, to assist the process of evaluating the performance of lecturers, a method/system is needed to be able to support decision making with predetermined criteria and it is able to rank the performance of each lecturer.

In this research, there were two methods used; Profile Matching and Technique for Order by Similarity to Ideal Solution (TOPSIS). Profile Matching method is a method in decision making that can compare the actual data value of a profile to be assessed with the expected profile value. (Sary Fatimah, Afriyudi, 2015). The Profile Matching method was chosen because it is suitable for use in supporting decision making related to organizational activities and human resource management (Purwanto, 2017).

The Technique for Order by Similarity to Ideal Solution (TOPSIS) method is a decision support method that has an easy to understand and simple concept (Prayetno et al., 2018), it is efficient computing, and able to measure the relative performance of alternative decisions in a simple mathematical form (Ifo Wahyu Pratama, 2018). The TOPSIS method was chosen because this method is able to help the optimal decision-making process to solve problems practically (Effendy \& Irawan, 2015). In addition, TOPSIS method can be integrated with other methods to deal with various specific problems (Primasari et al., 2018).

There are several previous researches that discuss the Profile Matching and TOPSIS methods including: selection of lecturer assistants using a combination of Profile Matching and TOPSIS methods. The Profile Matching method is used to calculate the parameters for the number of experiences and the number of courses registered and the TOPSIS method is used for ranking calculations. The results of the research concluded that the combination of methods used can be used to assist the lecturer coordinator of the courses in the selection process for teaching assistants (Somya \& Wardoyo, 2019), Then, research on the selection of goat species based on environmental and financial criteria in which the Profile Matching method is used to evaluate environmental suitability and TOPSIS for the decision-making process. The results of the research conclude that the methods used can be integrated and produce valid results and successfully represent the goat expert's considerations (Primasari et al., 2018).

Therefore, this research was conducted with the aim of implementing a combination of methods between Profile Matching and TOPSIS into a decision support system for assessing lecturer performance. The Profile Matching method is used to compare the competencies possessed by each individual with standard competencies (Eva Yulianti, 2017), In this case, it is about ideal performance profile of lecturers so that differences in competence can be known (also called gaps), the smaller the resulting gap, the greater the weight of the value (Setiyowati et al., 2019), The results of the calculation of the Profile Matching method are then processed by the TOPSIS method for ranking calculations which in this case will display the ranking of lecturers who have the best to the lowest performance.

\section{RESEARCH METHOD}

\section{Method of Data Collection}

The data collection method used in this research was divided into 2 mentioned below:

1. Conducting interviews, observations and questionnaires to obtain primary data.

2. Using information obtained from the databases of Higher Education and Central, as well as related archives/documents that support this research to obtain secondary data.

\section{Determination of Criteria and Sub-criteria}

The criteria and sub-criteria were taken from the Lecturer Performance Target (SKP), in which there were 4 criteria and 14 sub-criteria used, as follow:

1. Education and Teaching Criteria with subcriteria: conducting lectures, guiding KKN/PKN/PKL (internship), guiding students in producing final study reports.

2. Research Criteria with sub-criteria: producing scientific papers, disseminated research results, publication of research results, role in publications.

3. Community Service with sub-criteria: development of educational and research results 
that can be utilized by the community, training / counseling / assistance to the community.

4. Work behavior with sub criteria: service orientation, integrity, commitment, discipline, cooperation.

\section{Calculation Stages of Combined Profile Matching And TOPSIS Method} carried out:

The following are the stages of the research

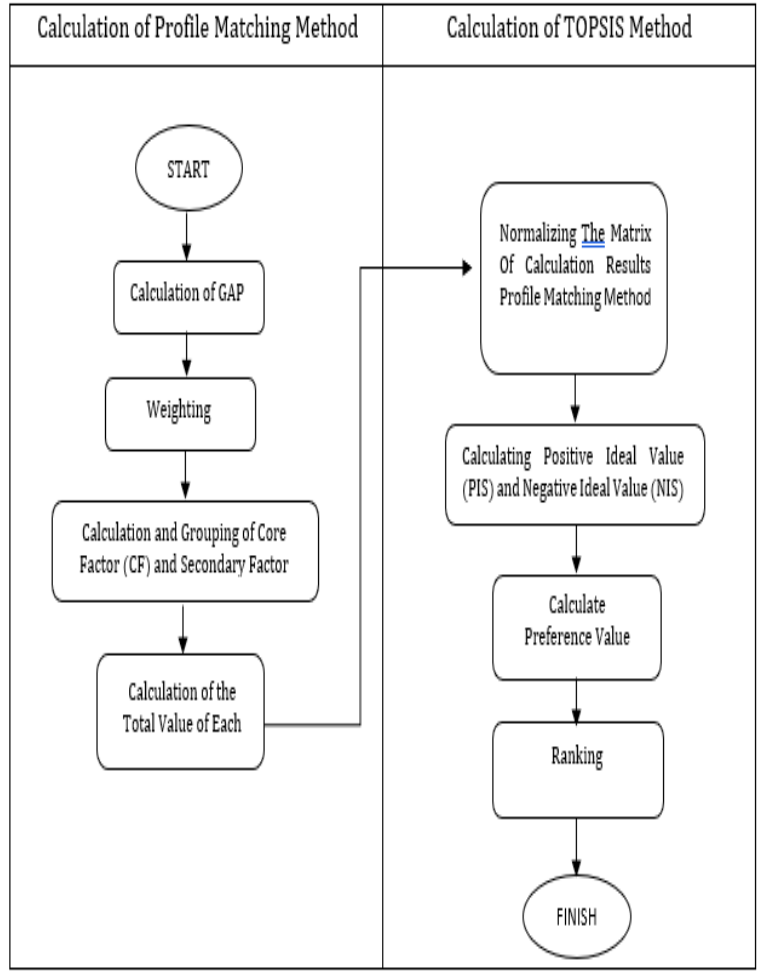

Figure 1. Stages of Calculation Method

1. Calculating Of GAP

The first step, it was staerted from the calculation of the GAP value in the Profile Matching method. Gap value can be formulated as follows: Gap = Employee Profile Value Position Profile Value (Ari Suhartanto, Kusrini, 2016). In this research, the gap was the difference between the lecturer profile performance profile, thus, the equation could be changed to Gap = Lecturer Profile Value Performance Profile Value

2. Weighting

After obtaining the GAP from each profile, it was given a weighted value with the benchmark of the GAP value weight table (Setiawan et al., 2017) as shown in Table 1.
Table 1. GAP Weight Value

\begin{tabular}{cclc}
\hline GAP & Weight & \multicolumn{1}{c}{ Information } \\
\hline 0 & 5 & No GAP (competence required) \\
\hline 1 & 4,5 & $\begin{array}{l}\text { Competence that has excess of 1 } \\
\text { level }\end{array}$ \\
\hline-1 & 4 & $\begin{array}{l}\text { Competence possessed less than } \\
\text { 1 level }\end{array}$ \\
\hline 2 & 3,5 & $\begin{array}{l}\text { Competencies possessed by } \\
\text { excess of 2 levels }\end{array}$ \\
\hline-2 & 3 & $\begin{array}{l}\text { Competence possessed less than } \\
\text { 2 levels }\end{array}$ \\
\hline 3 & 2,5 & $\begin{array}{l}\text { Competence } \\
\text { advantages of 3 levels }\end{array}$ \\
\hline-3 & 2 & $\begin{array}{l}\text { Competencies owned are less } \\
\text { than 3 levels }\end{array}$ \\
\hline 4 & 1,5 & $\begin{array}{l}\text { Competencies possessed by } 4 \\
\text { levels }\end{array}$ \\
\hline 4 & 1 & $\begin{array}{l}\text { Competencies owned are less } \\
\text { than 4 levels }\end{array}$ \\
\hline
\end{tabular}

3. Calculation and Grouping of Core Factor (CF) and Secondary Factor (SF)

Core factor (main factor) is the aspect of competence that is most needed in producing optimal performance. While the secondary factors (supporting factors) are items other than aspects owned by the core factor (Chairi et al., 2018). The following below is the equation for the core factor:

$\mathrm{NCF}=\frac{\sum \mathrm{NC}}{\sum \mathrm{IC}}$

The secondary factor equation is as follows :

$\mathrm{NSF}=\frac{\sum \mathrm{NS}}{\sum \mathrm{IS}}$

In which:

NCF: mean of core factor

NC: total value of core factor

IC: total item of core factor

NSF: mean of secondary factor

NS: total value of secondary factor

IS: total item secondary factor

4. Calculation of the Total Value of Each Aspect After the CF and SF values were obtained, then the total value of each aspect was calculated in each of the predetermined criteria on the performance of each profile (Warasto, 2016). The equation for the total value of each aspect was shown as follows:

$\mathrm{NT}=(\mathrm{X}) \% \mathrm{NCF}+(\mathrm{X}) \% \mathrm{NSF}$

In which: 
NCF : mean of core factor

NSF : mean of secondary factor

NT : total value

(x)\% : Percent value included

5. Normalizing the Profile Matching calculation matrix

After obtaining the total value of each aspect, the TOPSIS method would play a role in the combined Profile Matching - TOPSIS method. TOPSIS method was used for calculations in conducting performance assessments. The initial step taken by the TOPSIS method in the combined method of Profile Matching - TOPSIS was to normalize the matrix of the total value of each aspect from the calculation results of the Profile Matching method. After obtaining the value of the normalized matrix, proceed with the calculation of the weighted normalized decision matrix. The normalized decision matrix equation is shown as follows:

$r_{i j}=\frac{x_{i j}}{\sqrt{\sum_{i=1}^{m} x_{i j^{2}}}}$

While the weighted normalized matrix equation is shown as follows:

$X_{i j}=W_{i j} r_{i j}$

6. Calculating Positive Ideal Value (PIS) and Negative Ideal Value (NIS)

Determining the Positive Ideal Solution Matrix (PIS) using the following equation:

$A+=\left\{\left(\max y_{-} i j \mid j € J\right),\left(\min y_{-} i j \mid j € J '\right)\right.$,

$\left.\mathrm{i}=1,2,3, \ldots, \mathrm{m}\}=\mathrm{y}_{-} 1+\mathrm{y}_{-} 2+, \ldots, \mathrm{y}_{-} \mathrm{n}+\right\}$

Meanwhile, the equation used to determine NIS is:

$A-=\left\{\left(\max y_{-} i j \mid j € J\right),\left(\operatorname{miny} \_i j \mid j \in J^{\prime}\right)\right.$,

$\mathrm{i}=1,2,3, \ldots, \mathrm{m}\}=\mathrm{y} \_1-\mathrm{y} \_2-, \ldots, \mathrm{y} \_\mathrm{n}-\mathrm{\}}$

Calculating the Distance of Positive Ideal Value (PIS) and Negative Ideal Value (NIS), Calculation of positive ideal solution use the following equation:

$\mathrm{D}_{i}^{+}=\sqrt{\sum_{j=1}^{n}{ }^{n}\left(y_{i}^{+}-y_{i j}\right)^{2}}$

Calculation of the negative ideal solution used the following equation:
$\mathrm{D}_{i}^{-}=\sqrt{\sum_{j=1}^{n}{ }^{n}\left(y_{i j}-y_{i}^{-}\right)^{2}}$

7. Calculating Preference Value

Calculation of the Preference Value of each alternative is shown in the following equation:

$\mathrm{Vi}=\frac{D_{i}^{-}}{D_{i}^{+}+D_{i}^{-}}$

8. Ranking

The last step of the combined method of Profile Matching and TOPSIS was ranking. The ranking was conducted by sorting the preference values in descending order. The best alternative has the shortest distance to the positive ideal solution (PIS) and the farthest distance to the negative ideal solution (NIS) (Kristina, 2018).

\section{RESULT AND DISCUSSION}

\section{Weight}

The process of weighting the criteria and sub-criteria values was determined by the Higher Education Leaders. For the weighting of the criteria, if the values of the weights are added up, they must be $100 \%$ as shown in table 2 .

Table 2. Weight of Criteria Score

\begin{tabular}{cll}
\hline No & \multicolumn{1}{c}{ Criteria } & Weight \\
\hline 1 & Education and Teaching & $30 \%$ \\
\hline 2 & Research & $26 \%$ \\
\hline 3 & Community service & $24 \%$ \\
\hline 4 & Work Behavior & $20 \%$ \\
\hline \multicolumn{2}{c}{ Total } & $100 \%$ \\
\hline
\end{tabular}

For the sub criteria, the performance assessment indicators were used as reference obtained from the Higher Education Leaders and for the determination of the weight values using the ordinal scale assessment. The ordinal scale is based on a ranking that is ordered from a higher level to a lower level or vice versa (Sutinah, 2017). The ordinal scale used has a range of values from 1 to 5 . The indicator of the weight of the sub-criteria values is shown in Table 3. And the results of the determination of the weight of the sub-criteria values by the Higher Education Leaders are shown in Table 4. 
Table 3. Indicator of Weight Value of Sub Criteria

\begin{tabular}{|c|c|c|c|}
\hline code & Criteria & Sub-Criteria & Performance Assessment \\
\hline SC1 & \multirow{3}{*}{$\begin{array}{l}\text { Education } \\
\text { and Teaching }\end{array}$} & Conducting lecture & $\begin{array}{l}\text { a. Giving lectures with a total of } 6 \text { or more ceredits (score } \\
\text { 5) } \\
\text { b. Giving lectures with a total of less than } 6 \text { credits (score } \\
\text { 3) } \\
\text { c. Not carrying out lectures (score 1) }\end{array}$ \\
\hline SC2 & & $\begin{array}{l}\text { Guiding KKN, PKN, PKL } \\
\text { (internship) }\end{array}$ & $\begin{array}{ll}\text { a. } & \text { Guiding (score } 5) \\
\text { b. } & \text { Not guiding (score } 1)\end{array}$ \\
\hline SC3 & & $\begin{array}{l}\text { Guiding/supervising } \\
\text { students in producing } \\
\text { final study reports }\end{array}$ & $\begin{array}{l}\text { a. As supervisor and co-supervisor (score 5) } \\
\text { b. Only as main supervisor (score 3) } \\
\text { c. Only as a co-supervisor (score 2) } \\
\text { d. Not guiding (score 1) }\end{array}$ \\
\hline SC4 & \multirow{4}{*}{ Research } & $\begin{array}{l}\text { Producing Scientific } \\
\text { Research }\end{array}$ & $\begin{array}{l}\text { a. More than } 1 \text { researches per year (score } 5 \text { ) } \\
\text { b. } 1 \text { research per year (score } 3) \\
\text { c. Not producing (score } 1 \text { ) }\end{array}$ \\
\hline SC5 & & $\begin{array}{l}\text { disseminated research } \\
\text { results }\end{array}$ & $\begin{array}{l}\text { a. Internasional (score } 5 \text { ) } \\
\text { b. National (score } 3 \text { ) } \\
\text { c. } \quad \text { Not disseminated (score } 1 \text { ) } \\
\end{array}$ \\
\hline SC6 & & $\begin{array}{l}\text { Publication of research } \\
\text { results }\end{array}$ & $\begin{array}{l}\text { a. Internationally reputable (score 5) } \\
\text { b. International (score 4) } \\
\text { c. Nationally accredited (score 3) } \\
\text { d. Nationally not accredited (score 2) } \\
\text { e. Unpublished (score 1) }\end{array}$ \\
\hline SC7 & & The role in publication & $\begin{array}{ll}\text { a. } & \text { First author (score } 5) \\
\text { b. } & \text { Co-author (score } 3) \\
\text { c. } & \text { Not writing (score } 1)\end{array}$ \\
\hline SC8 & \multirow{2}{*}{$\begin{array}{l}\text { Community } \\
\text { service }\end{array}$} & $\begin{array}{l}\text { development of } \\
\text { educational and } \\
\text { research results that } \\
\text { can be utilized by the } \\
\text { community }\end{array}$ & $\begin{array}{l}\text { a. More than } 1 \text { (score } 5) \\
\text { b. Once in } 1 \text { year (score } 3) \\
\text { c. Not conducting (score } 1)\end{array}$ \\
\hline SC9 & & $\begin{array}{l}\text { training/ counselling / } \\
\text { assistance to the } \\
\text { community }\end{array}$ & $\begin{array}{ll}\text { a. } & \text { International Scale (score 4) } \\
\text { b. National Scale (score 3) } \\
\text { c. Local Scale (score 2) } \\
\text { d. } \quad \text { Not doing (score 1) }\end{array}$ \\
\hline SC10 & \multirow{5}{*}{$\begin{array}{l}\text { Work } \\
\text { Behavior }\end{array}$} & Service orientation & $\begin{array}{ll}\text { a. } & \text { Very Good (score 5) } \\
\text { b. } & \text { Good (score 4) } \\
\text { c. } & \text { Fairly Good (score 3) } \\
\text { d. } & \text { Poor (score 2) } \\
\text { e. } & \text { Very poor (score 1) } \\
\end{array}$ \\
\hline SC11 & & Integrity & $\begin{array}{ll}\text { a. } & \text { Very Good (score 5) } \\
\text { b. } & \text { Good (score 4) } \\
\text { c. } & \text { Fairly Good (score 3) } \\
\text { d. } & \text { Poor (score 2) } \\
\text { e. } & \text { Very poor (score 1) } \\
\end{array}$ \\
\hline SC12 & & Commitment & $\begin{array}{ll}\text { a. } & \text { Very Good (score 5) } \\
\text { b. } & \text { Good (score 4) } \\
\text { c. } & \text { Fairly Good (score 3) } \\
\text { d. } & \text { Poor (score 2) } \\
\text { e. } & \text { Very poor (score 1) } \\
\end{array}$ \\
\hline SC13 & & Discipline & $\begin{array}{ll}\text { a. } & \text { Very Good (score 5) } \\
\text { b. } & \text { Good (score 4) } \\
\text { c. } & \text { Fairly Good (score 3) } \\
\text { d. } & \text { Poor (score 2) } \\
\text { e. } & \text { Very poor (score 1) } \\
\end{array}$ \\
\hline SC14 & & Cooperation & $\begin{array}{ll}\text { a. } & \text { Very Good (score 5) } \\
\text { b. } & \text { Good (score 4) } \\
\text { c. } & \text { Fairly Good (score 3) } \\
\text { d. } & \text { Poor (score 2) } \\
\text { e. } & \text { Very poor (score 1) } \\
\end{array}$ \\
\hline
\end{tabular}


Table 4. The Result of Determining the Weight of the Sub Criteria

\begin{tabular}{|c|c|c|c|c|}
\hline Code & Criteria & Sub-Criteria & Score & Type \\
\hline SC1 & \multirow{3}{*}{$\begin{array}{l}\text { Education and } \\
\text { Teaching (30\%) }\end{array}$} & Conducting lecture & 5 & $\mathrm{CF}$ \\
\hline SC2 & & $\begin{array}{l}\text { Guiding/supervising KKN, PKN, PKL } \\
\text { (internship) }\end{array}$ & 5 & SF \\
\hline SC3 & & $\begin{array}{l}\text { Guiding/supervising students in } \\
\text { producing final study reports }\end{array}$ & 3 & $\mathrm{CF}$ \\
\hline SC4 & \multirow{4}{*}{$\begin{array}{l}\text { Research } \\
(26 \%)\end{array}$} & Producing Scientific Research & 5 & $\mathrm{CF}$ \\
\hline SC5 & & disseminated research results & 3 & SF \\
\hline SC6 & & Publication of research results & 3 & $\mathrm{CF}$ \\
\hline SC7 & & The role in publication & 5 & $\mathrm{SF}$ \\
\hline SC8 & \multirow[t]{2}{*}{$\begin{array}{l}\text { Community service } \\
(24 \%)\end{array}$} & $\begin{array}{l}\text { development of educational and } \\
\text { research results that can be utilized by } \\
\text { the community }\end{array}$ & 3 & $\mathrm{SF}$ \\
\hline SC9 & & $\begin{array}{l}\text { training/ counselling / assistance to } \\
\text { the community }\end{array}$ & 4 & $\mathrm{CF}$ \\
\hline SC10 & \multirow{5}{*}{$\begin{array}{l}\text { Work Behavior } \\
\qquad(20 \%)\end{array}$} & Service orientation & 4 & SF \\
\hline SC11 & & Integrity & 4 & $\mathrm{CF}$ \\
\hline SC12 & & Commitment & 4 & SF \\
\hline SC13 & & Discipline & 4 & $\mathrm{CF}$ \\
\hline SC14 & & Cooperation & 4 & $\mathrm{CF}$ \\
\hline
\end{tabular}

\section{Calculation of the Combined Profile Matching Method and TOPSIS}

In this research, a sample of 5 lecturers was taken. The five lecturers were given a code (L1) to (L5) and had a performance profile as shown in table 5 .

Table 5. Profile of Lecturers' Performance Sub- $\quad$ Profile of Lecturers' Performance

\begin{tabular}{cccccc} 
criteria & L1 & L2 & L3 & L4 & L5 \\
\hline SC1 & 5 & 5 & 5 & 5 & 5 \\
\hline SC2 & 5 & 5 & 5 & 5 & 5 \\
\hline SC3 & 3 & 3 & 2 & 5 & 5 \\
\hline SC4 & 5 & 5 & 5 & 5 & 5 \\
\hline SC5 & 1 & 1 & 1 & 1 & 2 \\
\hline SC6 & 2 & 3 & 2 & 2 & 4 \\
\hline SC7 & 4 & 4 & 5 & 5 & 4 \\
\hline SC8 & 5 & 5 & 5 & 5 & 5 \\
\hline SC9 & 2 & 2 & 2 & 2 & 2 \\
\hline SC10 & 4 & 4 & 5 & 4 & 4 \\
\hline SC11 & 4 & 5 & 5 & 4 & 4 \\
\hline SC12 & 4 & 5 & 4 & 4 & 5 \\
\hline SC13 & 4 & 5 & 4 & 4 & 3 \\
\hline SC14 & 4 & 5 & 5 & 4 & 4
\end{tabular}

\section{Calculation of GAP Value}

The GAP value is the difference between the lecturer profile - the performance profile. The calculation results are shown in table 6.
Table 6. GAP Calculation Result

\begin{tabular}{cccccc}
\hline \multirow{2}{*}{$\begin{array}{c}\text { Sub- } \\
\text { criteria }\end{array}$} & \multicolumn{4}{c}{ Profile of Lecturers' Performance } \\
\cline { 2 - 6 } & L1 & L2 & L3 & L4 & L5 \\
\hline SC1 & 0 & 0 & 0 & 0 & 0 \\
\hline SC2 & 0 & 0 & 0 & 0 & 0 \\
\hline SC3 & 0 & 0 & -1 & 2 & 2 \\
\hline SC4 & 0 & 0 & 0 & 0 & 0 \\
\hline SC5 & -2 & -2 & -2 & -2 & -1 \\
\hline SC6 & -1 & 0 & -1 & -1 & 1 \\
\hline SC7 & -1 & -1 & 0 & 0 & -1 \\
\hline SC8 & 0 & 0 & 0 & 0 & 0 \\
\hline SC9 & -2 & -2 & -2 & -2 & -2 \\
\hline SC10 & 0 & 0 & 1 & 0 & 0 \\
\hline SC11 & 0 & 1 & 1 & 0 & 0 \\
\hline SC12 & 0 & 1 & 0 & 0 & 1 \\
\hline SC13 & 0 & 1 & 0 & 0 & -1 \\
\hline SC14 & 0 & 1 & 1 & 0 & 0 \\
\hline
\end{tabular}

\section{Weight of GAP Value}

The results of the GAP calculation were then given a weighted value with reference to the GAP value weight table in table 1 . The weighting results are shown in table 7.

Table 7. Weight of GAP Value Result

\begin{tabular}{cccccc} 
Sub- & \multicolumn{5}{c}{ Profile of Lecturers' Performance } \\
\cline { 2 - 6 } criteria & L1 & L1 & L1 & L1 & L1 \\
\hline SC1 & 5 & 5 & 5 & 5 & 5 \\
\hline
\end{tabular}


JURNAL RISET INFORMATIKA

Vol. 3, No. 3 June 2021
P-ISSN: 2656-1743 |E-ISSN: 2656-1735

DOI: https://doi.org/10.34288/jri.v3i3.237

\begin{tabular}{cccccc}
\hline \multirow{2}{*}{$\begin{array}{c}\text { Sub- } \\
\text { criteria }\end{array}$} & \multicolumn{5}{c}{ Profile of Lecturers' Performance } \\
\cline { 2 - 6 } & L1 & L1 & L1 & L1 & L1 \\
\hline SC2 & 5 & 5 & 5 & 5 & 5 \\
\hline SC3 & 5 & 5 & 4 & 3.5 & 3.5 \\
\hline SC4 & 5 & 5 & 5 & 5 & 5 \\
\hline SC5 & 3 & 3 & 3 & 3 & 4 \\
\hline SC6 & 4 & 5 & 4 & 4 & 4.5 \\
\hline SC7 & 4 & 4 & 5 & 5 & 4 \\
\hline SC8 & 5 & 5 & 5 & 5 & 5 \\
\hline SC9 & 3 & 3 & 3 & 3 & 3 \\
\hline SC10 & 5 & 5 & 4.5 & 5 & 5 \\
\hline SC11 & 5 & 4.5 & 4.5 & 5 & 5 \\
\hline SC12 & 5 & 4.5 & 5 & 5 & 4.5 \\
\hline
\end{tabular}

\begin{tabular}{cccccc}
\hline \multirow{2}{*}{$\begin{array}{c}\text { Sub- } \\
\text { criteria }\end{array}$} & \multicolumn{5}{c}{ Profile of Lecturers' Performance } \\
\cline { 2 - 6 } & L1 & L1 & L1 & L1 & L1 \\
\hline SC13 & 5 & 4.5 & 5 & 5 & 4 \\
\hline SC14 & 5 & 4.5 & 4.5 & 5 & 5 \\
\hline
\end{tabular}

Calculation of Core Factor (CF) and Secondary Factor (SF)

The CF value/score was determined at $60 \%$ and the SF value was $40 \%$. Calculation of CF using equation 2 and SF using equation 3 . The calculation results are shown in table 8.

Table 8. Calculation Result of CF and SF

\begin{tabular}{|c|c|c|c|c|c|c|c|c|}
\hline \multirow{3}{*}{ Lecturer code } & \multicolumn{8}{|c|}{ Criteria } \\
\hline & \multicolumn{2}{|c|}{$\begin{array}{l}\text { Education and } \\
\text { Teaching }\end{array}$} & \multicolumn{2}{|c|}{ Research } & \multicolumn{2}{|c|}{ Community service } & \multicolumn{2}{|c|}{ Work Behavior } \\
\hline & $\mathrm{CF}$ & SF & $\mathrm{CF}$ & $\mathrm{SF}$ & $\mathrm{CF}$ & SF & $\mathrm{CF}$ & $\mathrm{SF}$ \\
\hline L1 & 5 & 5 & 4.5 & 3.5 & 3 & 5 & 5 & 5 \\
\hline $\mathrm{L} 2$ & 5 & 5 & 5 & 3.5 & 3 & 5 & 4.5 & 4.8 \\
\hline L3 & 4.5 & 5 & 4.5 & 4 & 3 & 5 & 4.7 & 4.8 \\
\hline $\mathrm{L} 4$ & 4.3 & 5 & 4.5 & 4 & 3 & 5 & 5 & 5 \\
\hline L5 & 4.3 & 5 & 4.8 & 4 & 3 & 5 & 4.7 & 4.8 \\
\hline
\end{tabular}

Calculation of the Total Value of Each Aspect

Calculation of the total value of each aspect used equation 3 . The results of the calculation of the total value of aspects are shown in table 9.

Table 9. Calculation Result of Total Aspect Value

\begin{tabular}{ccccc}
\hline \multirow{2}{*}{$\begin{array}{c}\text { Lectur } \\
\text { er } \\
\text { code }\end{array}$} & $\begin{array}{c}\text { Educati } \\
\text { on and } \\
\text { Teachin } \\
\text { g }\end{array}$ & $\begin{array}{c}\text { Resear } \\
\text { ch }\end{array}$ & $\begin{array}{c}\text { Commun } \\
\text { ity } \\
\text { service }\end{array}$ & $\begin{array}{c}\text { Work } \\
\text { Behavi } \\
\text { or }\end{array}$ \\
\hline L1 & 5 & 4.1 & 3.8 & 5 \\
\hline L2 & 5 & 4.4 & 3.8 & 4.6 \\
\hline L3 & 4.7 & 4.3 & 3.8 & 4.7 \\
\hline L4 & 4.6 & 4.3 & 3.8 & 5 \\
\hline L5 & 4.6 & 4.5 & 3.8 & 4.7 \\
\hline
\end{tabular}

Calculation of Weighted Normalized and Normalized Matrix.

Calculation of the normalized decision matrix using equation 5 . The calculation results are shown in Table 10 .

Table 10. Normalized Matrix Calculation Results

\begin{tabular}{ccccc}
\hline \multirow{2}{*}{$\begin{array}{c}\text { Lectur } \\
\text { er } \\
\text { code }\end{array}$} & $\begin{array}{c}\text { Educati } \\
\text { on and } \\
\text { Teachin } \\
\text { g }\end{array}$ & $\begin{array}{c}\text { Resear } \\
\text { ch }\end{array}$ & $\begin{array}{c}\text { Educati } \\
\text { on and } \\
\text { Teachin } \\
\text { g }\end{array}$ & $\begin{array}{c}\text { Work } \\
\text { Behavi } \\
\text { or }\end{array}$ \\
\hline L1 & 0.469 & 0.425 & 0.447 & 0.466 \\
\hline L2 & 0.469 & 0.456 & 0.447 & 0.428 \\
\hline L3 & 0.441 & 0.446 & 0.447 & 0.438 \\
\hline L4 & 0.427 & 0.446 & 0.447 & 0.466 \\
\hline L5 & 0.427 & 0.462 & 0.447 & 0.438 \\
\hline
\end{tabular}

Furthermore, the weighted normalized decision matrix was calculated using equation 6 . It was multiplying the normalized decision matrix by the weighted value of the criteria. The weight of the criteria is shown in Table 2 . The calculation results are shown in Table 11.

Table 11. Weighted Normalized Matrix Calculation Results

\begin{tabular}{|c|c|c|c|c|}
\hline \multirow[b]{2}{*}{$\begin{array}{l}\text { Lectur } \\
\text { er } \\
\text { code }\end{array}$} & \multicolumn{4}{|c|}{ Criteria } \\
\hline & $\begin{array}{c}\text { Educati } \\
\text { on and } \\
\text { Teachin } \\
\mathrm{g}\end{array}$ & $\begin{array}{c}\text { Resear } \\
\text { ch }\end{array}$ & $\begin{array}{c}\text { Commun } \\
\text { ity } \\
\text { service }\end{array}$ & $\begin{array}{c}\text { Work } \\
\text { Behavi } \\
\text { or }\end{array}$ \\
\hline L1 & 0.141 & 0.111 & 0.107 & 0.093 \\
\hline $\mathrm{L} 2$ & 0.141 & 0.119 & 0.107 & 0.086 \\
\hline L3 & 0.132 & 0.116 & 0.107 & 0.088 \\
\hline $\mathrm{L} 4$ & 0.128 & 0.116 & 0.107 & 0.093 \\
\hline
\end{tabular}




\begin{tabular}{ccccc}
\hline \multirow{2}{*}{$\begin{array}{c}\text { Lectur } \\
\text { er } \\
\text { code }\end{array}$} & $\begin{array}{c}\text { Educati } \\
\text { on and } \\
\text { Teachin } \\
\text { g }\end{array}$ & $\begin{array}{c}\text { Resear } \\
\text { ch }\end{array}$ & $\begin{array}{c}\text { Commun } \\
\text { ity } \\
\text { service }\end{array}$ & $\begin{array}{c}\text { Work } \\
\text { Behavi } \\
\text { or }\end{array}$ \\
\hline L5 & 0.128 & 0.120 & 0.107 & 0.088 \\
\hline
\end{tabular}

Calculation of positive ideal value (PIS) and negative ideal value (NIS)

After obtaining the value of the weighted normalized decision matrix, the next step was to determine the positive ideal value (PIS) and negative ideal value (NIS). The calculation of the PIS value used equation 7 and equation 8 for NIS. The following is the result of calculating the value of the Positive Ideal Solution (PIS):

$\mathrm{A}+=0.141 ; 0.120 ; 0.107 ; 0.093$

The result of calculating the value of the Negative Ideal Solution (NIS) :

$$
\text { A- } \quad=0.128 ; 0.111 ; 0.107 ; 0.088
$$

Furthermore, it was to determine the alternative distance to the positive ideal value (PIS) and negative ideal value (NIS). To determine the distance of each alternative to the positive ideal value (PIS) used equation 9 and the negative ideal value (NIS) used equation 10. The calculation results of PIS and NIS are shown in Table 12.

Table 12. Calculation result of PIS and NIS

\begin{tabular}{ccc}
\hline $\begin{array}{c}\text { Lecturer's } \\
\text { code }\end{array}$ & $\begin{array}{c}\text { Positive Ideal } \\
\text { Solution (PIS) } \\
\text { (D+) }\end{array}$ & $\begin{array}{c}\text { Negative Ideal } \\
\text { Solution (NIS) } \\
\text { (D-) }\end{array}$ \\
\hline L1 & 0.0094387 & 0.0146992 \\
\hline L2 & 0.0075701 & 0.0150344 \\
\hline L3 & 0.0109061 & 0.0070993 \\
\hline L4 & 0.0133020 & 0.0091966 \\
\hline L5 & 0.0138489 & 0.0096206 \\
\hline
\end{tabular}

\section{Calculation of preference weight value}

To calculate the preference weight value, it used equation 11 . The results of the preference weight calculation are shown in Table 13.

Table 13. Profile Matching Preference Weight Calculation Results And TOPSIS

\begin{tabular}{cc}
\hline Lecturer Code & Preference Weight \\
\hline L1 & 0.608969 \\
\hline L2 & 0.665107 \\
\hline L3 & 0.394287 \\
\hline L4 & 0.408765 \\
\hline L5 & 0.409920 \\
\hline
\end{tabular}

\section{Ranking}

The ranking results were obtained based on the results of the calculation of preference weight (Vi). The ranking displays lecturers with the highest to lowest performance as shown in Table 14.

Table 14 Ranking Result

\begin{tabular}{ccl}
\hline $\begin{array}{c}\text { Lecturer } \\
\text { Code }\end{array}$ & Final Score & Ranking \\
\hline L2 & 0.665107 & $1^{\text {st }}$ place \\
\hline L1 & 0.608969 & $2^{\text {nd }}$ place \\
\hline L5 & 0.409920 & $3^{\text {rd }}$ place \\
\hline L4 & 0.408765 & $4^{\text {th }}$ place \\
\hline L3 & 0.394287 & $5^{\text {th }}$ place \\
\hline
\end{tabular}

Table 14 shows the lecturer with the L2 code as the lecturer with the best performance with a final score of 0.665107 , while the lecturer with the L3 code became the lecturer with the lowest performance with a final score of 0.394287 .

\section{System Implementation}

The following is a description of the user interface of the Lecturer Performance Assessment Decision Support System.

1. Login Page

The login page was created to validate the access owned by the user. To login to the decision support system, this lecturer's performance assessment required input of the correct username and password.

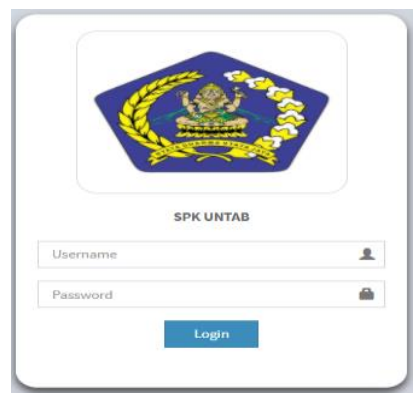

Figure 2. Login Page

2. Criteria and Sub Criteria Data Pages

This page had a function to display the criteria and sub-criteria as well as the weight value of each criterion and sub-criteria used as a guide in evaluating lecturer performance. The data on this criteria and sub-criteria page could be added, changed or deleted. 

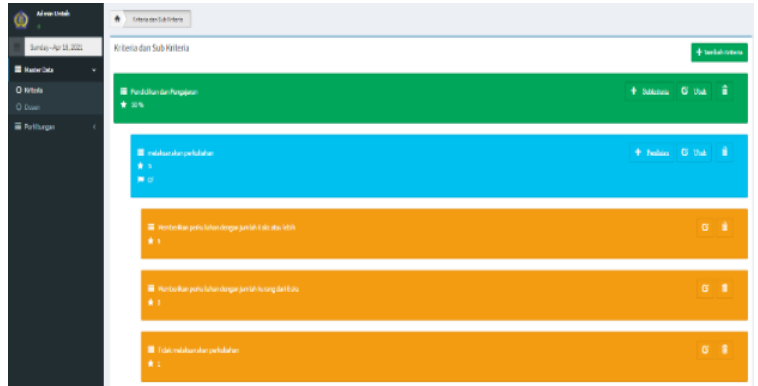

Figure 3. Criteria and Sub-criteria Data Page Subkriteria

3. Page of Lecturers' Data

This page served to display lecturer data that would be processed using a decision support system for assessing lecturer performance. On the lecturer data page, the user/admin could add lecturer data, change or delete lecturer data.

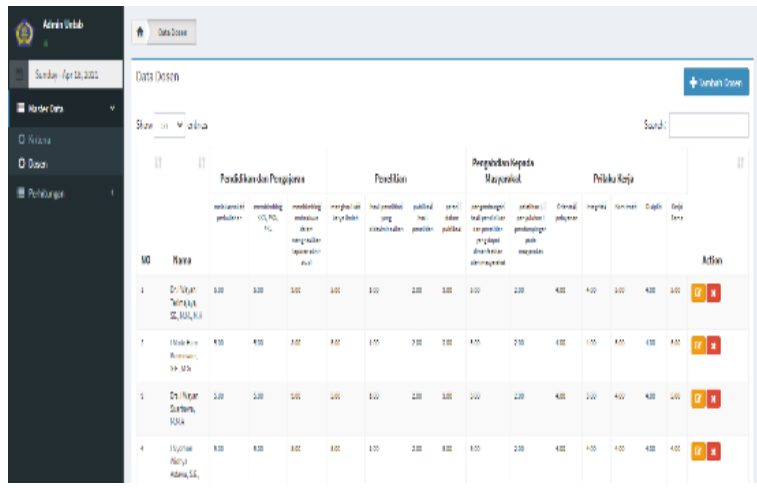

Figure 4. Lecturer Data Page

4. Calculation Page

The calculation page had a function to perform calculations on the performance of each lecturer. In addition, on this page, it could also filter the period or academic year for performance appraisals and print out lecturers' performance reports based on pre-determined periods/school years.

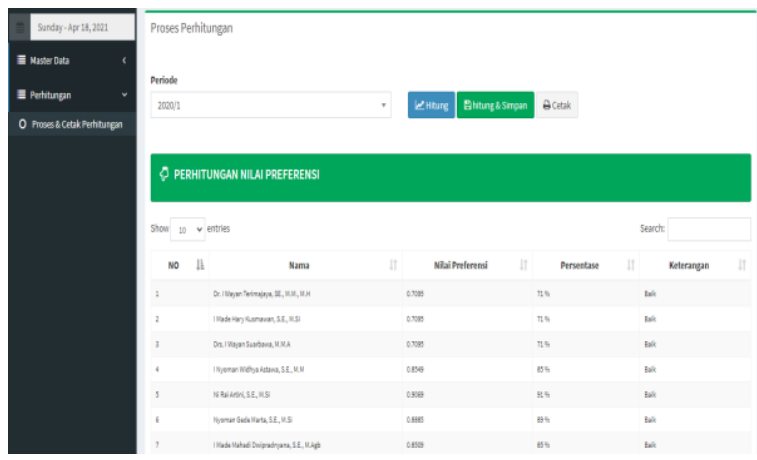

Figure 5. Calculation Page

\section{CONCLUSION AND SUGGESTION}

\section{Conclusion}

According to the results of the research that has been conducted, it can be drawn the conclusion that: in combining the methods between Profile Matching and TOPSIS, the Profile Matching method is used to compare the competencies possessed by each individual with standard competencies. This research is the expected performance profile of the leader with the desired performance profile owned by each lecturer and it calculates the value of the level of compatibility of each predetermined alternative, while the TOPSIS method for ranking calculations. In this case, it will display the ranking of lecturers who have the best and highest performance to the lowest. Furthermore, the combined method of Profile Matching and TOPSIS is implemented into the Decision Support System (SPK) in order to assist the Tabanan University, especially the Higher Education Leaders in assessing the performance of lecturers. SPK can ease leaders to rank/sort lecturers' performance.

\section{Suggestion}

Based on the results of research as stated previously, several things can be suggested, as follow: it is necessary to add other criteria and subcriteria to further support the results in assessing the performance of lecturers and. For the further researchers who want to develop this research, they can perform calculations using other DSS methods as a comparison of results.

\section{REFERENCES}

Agustini, S. P. (2017). Rancang Bangun Sistem Informasi Evaluasi Dosen Universitas Muhammadiyah. Cybernetics, 1(02), 58. https://doi.org/10.29406/cbn.v1i02.555

Ari Suhartanto, Kusrini, H. (2016). Decision Support System Untuk Penilaian Kinerja Guru Dengan Metode Profile Matching. Jurnal Komputer Terapan, 2(2), 149-158.

Chairi, A., Putri, R. R. M., \& Fanani, L. (2018). Rekomendasi Tempat Wisata Kota Malang Menggunakan Metode Profile Matching Dan Saran Rute Menggunakan Floyd Warshall Berbasis Android. Jurnal Pengembangan Teknologi Informasi Dan Ilmu Komputer EISSN: 2548-964X, 2(5), 2060-2069. http://jptiik.ub.ac.id

Effendy, D. A., \& Irawan, R. H. (2015). Uji Sensitivitas metode WP, SAW Dan TOPSIS Dalam Menentukan Titik Lokasi Repeater Internet Wireless. Seminar Nasional Teknologi Informasi Dan Multimedia, 6-8.

Eva Yulianti, D. S. (2017). Komparasi Metode Profile 
Matching dan Topsis dalam Seleksi Penerimaan Asisten Pratikum Studi Kasus (Laboratorium Teknik Informatika Institut Teknologi Padang). Seminar Nasional Peranan Ipteks Menuju Industri Masa Depan (PIMIMD4) Institut Teknologi Padang (ITP), 78-86. https://doi.org/10.21063/pimimd4.2017.7886

Ifo Wahyu Pratama. (2018). Sistem Pendukung Keputusan Evaluasi Kinerja Dosen dengan Metode Technique For Order By Similarity To Ideal Solution ( Topsis ) \& Preference Ranking Organization For Evaluation ( Promethee ). Jurnal Cendikia, XV(April), 35-42.

Kristina, T. (2018). Sistem Pendukung Keputusan Dengan Menggunakan Metode TOPSIS Untuk Pemilihan Lokasi Pendirian Grosir Pulsa. Paradigma, 20(1), 8-12.

Kusumastuti, I., ita Kurniawati, N., Loka Satria, D., \& Wicaksono, D. (2019). Analisis Pengaruh Lingkungan Kerja Terhadap Kinerja Karyawan Dimediasi Oleh Kepuasan Kerja Karyawan Pada Sp Alumunium Di Yogyakarta. Jurnal Riset Ekonomi Manajemen (REKOMEN), $3(1)$, $43-53$ https://doi.org/10.31002/rn.v3i1.1540

Latief, M. (2018). Peran LPTK Dalam Pengembangan Pendidikan Vokasi di Indonesia Peran LPTK Dalam Pengembangan Pendidikan Vokasi di Indonesia. Seminar Internasional, ISSN, 1907-2066, 231-238.

Prayetno, D., Sinaga, M. D., Sari, R. E., Utama, U. P., Yos, J. K. L., Km, S., Tanjung, N., \& Medan, M. (2018). Sistem Pendukung Keputusan Menentukan Kadar Minyak Mentah Kelapa Sawit Dengan Metode Topsis.

Primasari, C. H., Wardoyo, R., \& Sari, A. K. (2018). Integrated AHP, profile matching, and TOPSIS for selecting type of goats based on environmental and financial criteria. International Journal of Advances in Intelligent
Informatics, $\quad 4(1), \quad 28-39$. https://doi.org/10.26555/ijain.v4i1.105

Purwanto, H. (2017). PEnerapan Metode Profile Matching Dalam Sistem Pendukung Keputusan Penilaian Kinerja Karyawan Pada Pt. Hyundai Mobil Indonesia Cabang Kalimalang. Jurnal Techno Nusa Mandiri, XIV(1), 15-20.

Sary Fatimah, Afriyudi, E. S. (2015). Penerapan Metode Profile Mathcing untuk Pencarian Siswa Penerima Beasiswa Kurang Mampu dan Berprestasi. Penerapan Metode Profile Mathcing Untuk Pencarian Siswa Penerima Beasiswa Kurang Mampu Dan Berprestasi.

Setiawan, A., Andreswari, D., \& Coestera, F. F. (2017). GAp Dan Profile Matching Untuk Seleksi Penerimaan Penyiar Radio ( Studi Kasus PT Radio Swaraunib FM ). Jurnal Rekursif, 5(3), 249-259.

Setiyowati, A., Ramadhani, L. A., \& Amin, M. K. (2019). Sistem Pendukung Keputusan Menentukan Penerima Beasiswa Kurang Mampu Menggunakan Metode Profile Matching. Jurnal Informatika Upgris, 5(1), 1-5. https://doi.org/10.26877/jiu.v5i1.3681

Somya, R., \& Wardoyo, R. (2019). Perancangan SPK Seleksi Asisten Dosen menggunakan Kombinasi Metode Profile Matching dan TOPSIS Berbasis Web Service. Khazanah Informatika: Jurnal Ilmu Komputer Dan Informatika, 5(1), 44-50. https://doi.org/10.23917/khif.v5i1.7924

Sutinah, E. (2017). Sistem Pendukung Keputusan Menggunakan Metode Profile Matching dalam Pemilihan Salesman Terbaik. Informatics for Educators and Professionals, 2(1), 234409.

Warasto, D. (2016). Sistem Pendukung Keputusan Evaluasi Kinerja Mahasiswa Dengan Metode Profile. Jurnal Informatika, 10(1), 1180-1188. https://doi.org/10.26555/jifo.v10i1.a3350 